\title{
Needle in a Haystack: Predicting the Occurrence of Wetland Invertebrates on the Basis of Simple Geographical Data. A Case Study on Two Threatened Micro-Mollusc Species (Gastropoda: Vertiginidae) from Poland
}

\author{
Zofia Książkiewicz $^{1}$ - Bartłomiej Gołdyn ${ }^{1,2}$
}

Received: 10 February 2015 / Accepted: 7 April 2015 / Published online: 25 April 2015

(C) The Author(s) 2015. This article is published with open access at Springerlink.com

\begin{abstract}
The aim of this study was to evaluate whether simple geographical data can be used to predict the probability of the presence of two threatened snail species: Vertigo angustior and $V$. moulinsiana, occurring within wetland areas across their central European range. Our research was based on data from 226 localities across Poland fitting with the species requirements according to the current literature. We used Canonical Variance Analysis with variance partitioning and tree classifications to model relationships between the species presence/absence and rough geographic features describing each locality (landscape and geomorphological types and hydrography). Our results have shown that the localities of the studied species are related to particular types of landform and landscape and are not distributed uniformly. Both species occur predominantly in young postglacial lowland landscapes and are usually associated with particular succession stages of lakes, with $V$. moulinsiana occurring in earlier phases of habitat evolution. Results from modelling show that cost- and time effectiveness of surveying for these species could be substantially increased by avoiding particular location types. The prediction models presented will be a useful tool for
\end{abstract}

Electronic supplementary material The online version of this article (doi:10.1007/s13157-015-0656-0) contains supplementary material, which is available to authorized users.

Bartłomiej Gołdyn

glodny@amu.edu.pl

1 Department of General Zoology, Faculty of Biology, Adam Mickiewicz University, Umultowska 89, 61-614 Poznań, Poland

2 Laboratorio de Ecología Natural y Aplicada de Invertebrados, Universidad Estatal Amazónica, Puyo, Ecuador planning future surveys of the vertiginids and in studies on their ecology and distribution.

Keywords Habitat loss · Terrestrial gastropods · Environmental survey $\cdot$ Prediction · Conservation biology . Natura 2000

\section{Introduction}

Studies on small invertebrate species are often challenging since such species are easy to overlook. The problem is even more pronounced when the target species are rare and/or protected - conservation plans tend to be based on incomplete distribution data. Many countries try to effectively protect such species simply by protection of their habitats (e.g. Natura 2000 network in Europe, Endangered Species Protection Program and U.S. Fish and Wildlife Services in USA, National Conservation Plan in Canada). Not all of these habitats however will host the species and - on the other hand - not all of the localities hosting such species had been discovered and/or taken under the conservation schemes. The problem and, thus, reduction in extinction risk of isolated populations require a reliable methodology for surveys of such localities (Egoh et al. 2014).

Such methodology should include a testable and easy-touse prediction framework, enabling selection of the most promising sites for fieldwork and omitting those in which probability of finding the species is negligible (Guisan et al. 2006). The development of such a methodology will increase the time- and cost effectiveness of the surveys. It will also enable foreseeing potential conflicts of interest between nature conservation and industry on the level of investment planning. Such a method of prediction should be adjusted to the ecology 
of particular species and should be based on results of a number of surveys covering a wide geographical range. It is especially needed for species that are difficult to detect in the field, because in such cases the gains from reducing the study effort will be greatest.

One of the most endangered invertebrate groups are the molluscs. They have the highest number of documented extinctions of any major taxonomic group, with non-marine species constituting $99 \%$ of all molluscan extinctions (Lydeard et al. 2004). Snails are often one of the most suitable groups when assessing the state of endangered habitats (Bedford and Godwin 2003; Ponder and Walker 2003; Steinitz et al. 2005; Stewart 2006; Ormerod et al. 2010; Murugesan et al. 2011; Oke 2013). Some Vertigo species, for instance, constitute an important element of well-preserved fen habitats (e.g. Šefferová Stanová et al. 2008) and are used as one of the indicators of wetland integrity in the European Union under the Habitats Directive (Colling and Schröder 2005a, b). Additionally, the role of terrestrial molluscs in litter decomposition and nutrient cycling in ecosystems is substantial (Cook 2001; Bardgett 2005). Thus, detecting the most endangered molluscan species and implementing conservation measures may also assist in the preservation of endangered ecosystems (Ormerod et al. 2010).

The main goal of our research was to find a way to make the surveys for potential wetland sites of endangered gastropod species more effective. We used simple geographical data to check if such information can be useful when predicting which areas have the highest and lowest probabilities of the presence of two snail species: Vertigo angustior (Jeffreys, 1830) and V. moulinsiana (Dupuy, 1849) within their central European range. Both snails are threatened across the EU and listed in Annex II of the UE Habitats Directive and in red lists of many European countries (Książkiewicz 2014). Their small size (the height of the shell does not exceed $5 \mathrm{~mm}$ ) and cryptic way of life (they are often litter- or soildwellers) make studies of these species complicated and time-consuming (Horsàk 2003).

In central Europe, $V$. moulinsiana and $V$. angustior are known to occur in open wetland localities where moisture levels are high and relatively constant (e.g. fens and sedge meadows, Pokryszko 1990; Killeen 2003; Książkiewicz 2010). However, $V$. moulinsiana is more restrictive with respect to moisture level than $V$. angustior and usually inhabits permanently wet or temporarily flooded areas (Killeen 2003; Cameron et al. 2003). V. moulinsiana prefers habitats that are overgrown with tall monocotyledons, moving up and down the stems to obtain desired humidities (Pokryszko 1990; Hornung et al. 2003; Killeen 2003; Myzyk 2011; von Proschwitz 2003). In contrast, $V$. angustior is a litter-dweller, staying within a few centimetres of the soil and litter (Norris and Colville 1974; Cameron et al. 2003) and does not tolerate inundation (Cameron et al. 2003; Jankowiak and Bernard 2013; Książkiewicz 2014).

Until recently, the recognition of the species distribution over central Europe was very poor - e.g. in Poland in 2002 only four localities of $V$. moulinsiana and 20 of $V$. angustior were known. The situation has improved since 2007 and current literature reports up to 30 localities of $V$. moulinsiana and 100 localities of $V$. angustior in Poland (Książkiewicz et al. 2012; Lipińska et al. 2012). Many remaining habitats and populations (many of which may be currently unrecognised) are seriously endangered by eutrophication and natural succession resulting from abandonment of extensive usage, changes in water level, and potential infrastructure investments (e.g. Pokryszko 2003; Stebbings and Killeen 1998). It is therefore necessary to develop a strategy for effective surveys of localities of these species based on a method allowing for pinpointing areas with the highest probability of their occurrences (Guisan et al. 2006).

In this paper, we present the results of statistical modelling with the potential to increase the effectiveness of future surveys and reduce the risk of destroying small and, therefore, difficult-to-trace wetland refugia of rare vertiginid species.

\section{Methods}

Data was collected from nature conservation assessment surveys that were conducted mainly for national parks and forestry purposes. Our research was based on data from 226 localities (Fig. 1) surveyed in western, northwestern (162 localities in total), eastern (14), and southern (50) Poland during 2007-2013 (see Książkiewicz et al. 2015 for details on sampling sites).

For the surveys we selected wetlands that fitted the requirements of $V$. moulinsiana and/or $V$. angustior. We had focused on marshes covered with sedges and reed beds as well as alkaline fens located in lowland, highland, and mountainous areas (Pokryszko 1990; Killeen 2003; Cameron et al. 2003). Potential habitats were chosen based on maps, aerial photographs, and interviews with naturalists and foresters.

Because V. angustior and V. moulinsiana are rare and strictly protected by the European law we applied the least invasive method of field research. Snails were searched in situ, visually on vegetation and within litter and soil by one or both authors for at least $30 \mathrm{~min}$, depending on the habitat area and heterogeneity. The amount of time is adequate for such surveys since experienced malacologists are generally able to detect the presence of these vertiginid species within 10 min of surveys in central European wetlands (Gołdyn and Książkiewicz in preparation).

The leaves and stems of monocots were carefully examined for $V$. moulinsiana. Litter and topsoil was sieved using a $0.5 \mathrm{~mm}$ sieve. Both fractions (i.e. particles passed through 


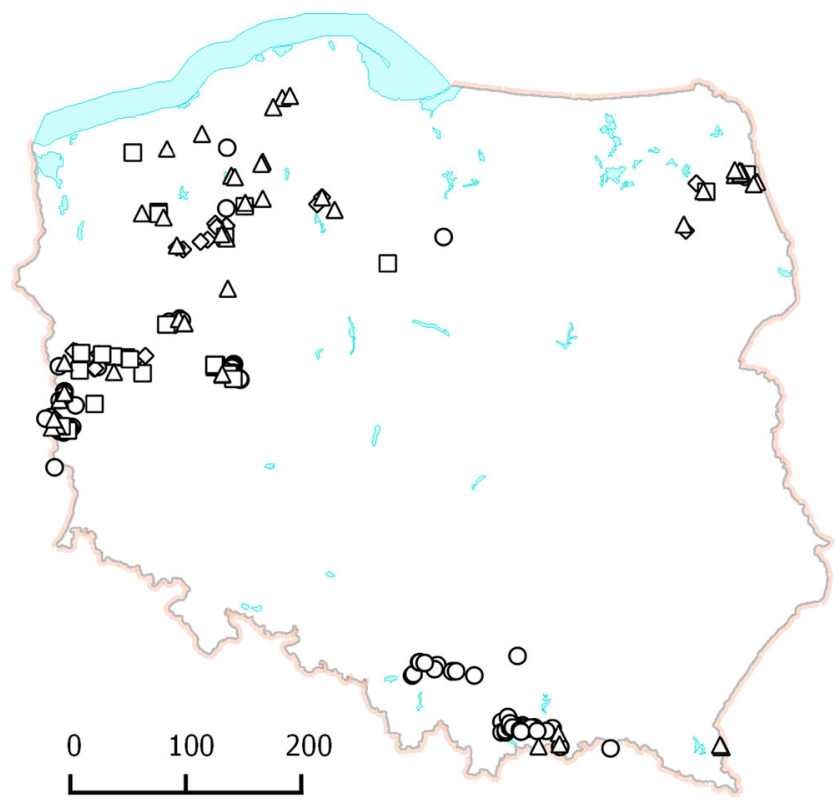

Fig. 1 Distribution of the surveyed localities over the map of Poland. Triangles: sites where $V$. angustior was recorded; squares: $V$. moulinsiana; diamonds: both species; circles: none of the species

the sieve and particles bigger than $0.5 \mathrm{~mm}$ in diameter) were separately examined on a white sheet of paper, using a magnifying glass.

In habitats where neither $V$. angustior nor $V$. moulinsiana were found, 21 of the litter and topsoil were collected from ca 10 randomly chosen spots and processed in the laboratory. Each of the samples were dried and sieved using a $0.5 \mathrm{~mm}$ sieve. Particles passed through the sieve were examined using a stereo microscope. The $>0.5 \mathrm{~mm}$ fraction was checked using magnifying glass (Książkiewicz 2010).

Geomorphological landform of the terrain surrounding each locality and type of landscape were determined based on the classifications of Richling and Ostaszewska (2005; Table 1). Data regarding the general character of the locality were collected, specifying whether the surveyed plot was located in a river floodplain, lake marsh, small river valley, or temporary water body. Localisation of each plot was determined using a GPS device, and altitude was taken from topographic maps of 1:10 000 scale.

The localities were analysed for relationships between snail occurrences and geographical characteristics using Canonical Varieties Analysis (CVA) performed with CANOCO 4.5 (ter Braak and Šmilauer 2002) software. Because the species often coexist in the same locality, one model was created to test the occurrence of both species (general model) and two subsequent analyses investigated each species separately.

Geomorphological landforms and landscape types as well as altitude are not distributed evenly in Poland. The southern part of the country is covered by highlands and mountains, whereas the northern and central parts are lowland plains dominated by postglacial forms. Thus, to evaluate whether morphology of terrain (landscape, landform, and character of the site) or its geographical location (altitude, latitude, and longitude) is more important, a variance-partitioning approach was conducted for each of the CVA models created (ter Braak 1996).

The environmental variables used in the analyses were grouped into two sets: the first was composed of site location and the second included the geomorphological data. Occurrences of vertiginid populations recorded during the surveys were included as dependent variables. Variance partitioning models were then created to separate the contributions of factors from both groups in explaining the occurrences of the studied species. Five separate CVA analyses were performed, each of them composed of data on localisation and geomorphology separately or accompanied with variables from the second group as covariables (Borcard et al. 1992). The results were compared with respect to the variance in species data explained by each model.

Variables included in the CVA models were subjected to the forward selection procedure with the Monte Carlo permutation test (5000 permutations). The overall significance of the models also was analysed with the same test. In all the statistical analyses, we considered $p=0.05$ as the minimum level when determining significance.

To make our results useful for efficient planning of future surveys, classification trees of sampled localities were created for each species. The trees show the probability of finding the given species when following one of the decision branches (nodes) with respect to the variables describing the potential site considered for a survey. Because the explanatory variables overlap partially (i.e., each site is located within one landform, one landscape type, and one descriptive category), three trees were created for each species, each of them showing classification for one such group of variables. Prior to the analysis, the dataset was randomly divided into two subsets containing equal numbers of cases. The first subset was used in the analysis as a training sample for building the model, while the other one was used for testing. The CHAID technique was used as a tree-growing method (Kass 1980). Significance values were adjusted using the Bonferroni method. Calculations were performed using SPSS 19.

\section{Results}

Vertigo moulinsiana was recorded in 71 and V. angustior in 88 of the 226 localities surveyed. Both species co-occurred in 41 localities.

The general CVA model showed (Fig. 2, Table 2) that with respect to the landscape forms both species occurred significantly more often in flat glaciofluvial landscapes and were not present in flooded plains. Moreover, the chances of finding $V$. angustior localities on siliceous uplands was also higher 
Table 1 Types of landforms and landscapes (Richling and Ostaszewska 2005) considered in the analyses

Landform types

Refashioned landforms due to glacial and glacio-fluvial deposition — in older moraine landscapes: degradational plains

Landforms due to glacial and glacio-fluvial deposition in the young moraine landscapes: outwash plains

Landforms due to glacial and glacio-fluvial deposition in the young moraine landscapes: morainic plateaus

Refashioned landforms due to glacial and glacio-fluvial deposition — in older moraine landscapes: assemblages of small thaw basins and single large thaw basins

Refashioned landforms due to glacial and glacio-fluvial deposition - in older moraine landscapes: relic terminal moraine ridges and hills

Horizontal and subhorizontal structures composed of Mesozoic and Neogene sedimentary rocks, affected by differentia uplift in Neogene and Quaternary times: drift-free plateaus and upland ridges of intermediate height

Flysch mountains folded in the Neogene: foothills

Flysch mountains folded in the Neogene: mountains of intermediate height and low mountains de résistance, residuals

Landforms due to fluvial accumulation: terrace flats (Pleistocene)

Landforms due to fluvial accumulation: flood-plains and supra-flood plains (Holocene)

Landforms due to glacial and fluvio-glacial deposition in the young moraine landscapes: kames, eskers

Aeolian landforms (Late Glacial and Holocene): wind-blown sandy areas

Landforms of biogenic origin (Holocene): peat plains

Landscape types

Lowland landscapes, glacial: flat and rolling

Lowland landscapes, glaciofluvial: flat and rolling

Lowland landscapes, glacial: hilly

Lowland landscapes, glacial: hummocky

Lowland landscapes, peryglacial: hummocky

Lowland landscapes, eolian: hilly

Upland and low mountainous landscapes: siliceous and aluminosiliceous - erosive: forelands and low mountains

Upland and low mountainous landscapes: carbonate and gypsum, erosive; compact massifs with klippes

Valley and depression landscapes, overflood terraces - accumulative: terrace plains on lowlands and uplands

Highland and high mountainous landscapes: highland - erosive, lower subalpine forest

Valley and depression landscapes: marshy plains - accumulative

Valley and depression landscapes: flooded valley bottoms — accumulative, flooded plains on lowlands and uplands
Abbreviation

degradational_plains

outwash_plains

morainic plateaus

thaw_basins

moraine_ridges

upland_ridges

foothills

intermediate_mountains

terrace_flats

holocene_flood-plains

kames_eskers

sandy_wind-blown

peat plains

flat_glacial

flat_glaciofluvial

hilly_glacial

hummocky_glacial

hummocky_peryglacial

hilly_eolian

siliceous_uplands

carbonate_uplands

terrace plains

accumulative_plains

marshy_plains

flooded_plains than in the wetlands located in other landscapes. Wetlands in the landform types described as Holocene flood-plains and intermediate mountains were not favourable sites for Vertigo surveys, whereas those on morainic plateaus were found to be the most promising localities. Locality character and its geographical location was also important, with the following variables being significantly related to the species occurrence: marshes, floodplain, valley, longitude and latitude. The whole model explained $60.1 \%$ of variance in species occurrences and was significant at the $p<0.001, F=15.42$ level. Variance partitioning revealed that geographical location (latitude and longitude) of the sampling plots alone explained a negligible portion of variance $(3.4 \%)$ compared to the group of other factors analysed $(37.3 \%)$ and the variance common to the two groups of variables $(19.4 \%)$.

The CVA model for $V$. moulinsiana showed that the species occurs significantly more often in flat glaciofluvial landscapes and in geomorphological landforms of morainic plateaus
(Table 3). The species is likely to be found in lake marshes and small river valleys, but floodplains and holocene floodplain landforms are devoid of $V$. moulinsiana. Although the species was recorded more often in localities in the northern and western parts of Poland, variance partitioning showed that this relationship is of secondary importance. Localisation exclusively explained $3.5 \%$ of variance and shared $10.7 \%$ of explained variance with other factors. The whole model explained $48.2 \%$ of variance in the species occurrences and was significant at the $p<0.001, F=9.60$ level.

Similarly, $V$. angustior tends to occur in sites located in small river valleys but not in floodplains (Table 4). The occurrence of the species is also connected to lake marshes; this relationship is, however, weaker compared to that of $V$. moulinsiana. Vertigo angustior occurred significantly less frequently in the wetlands of accumulative plains and the flooded plains landscape type and was common in wetlands of outwash plains. It was also recorded more often in localities 


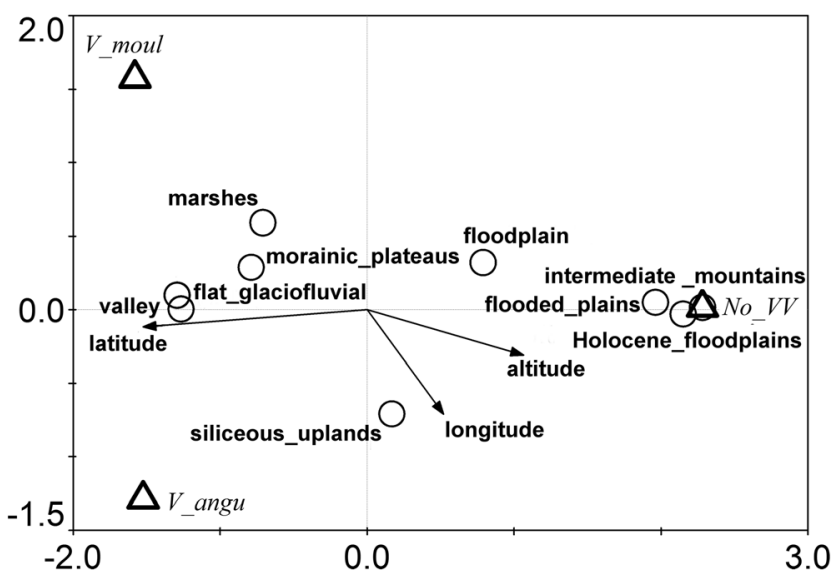

Fig. 2 CVA diagram showing the relationships between the occurrences of the two studied species (triangles) and the factors analysed (circles and arrows); No_VV=localities, where neither $V$. moilinsiana nor $V$. angustior occurred; see Table 1 for abbreviations

in the northern and western parts of Poland - again however, the significance of the geographical location was caused by the spatial distribution of other factors analysed. This group of factors exclusively explained $4.0 \%$ of variance and shared $16.1 \%$ with variables describing geomorphology. The whole model explained $48.2 \%$ of variance in the species occurrences and was significant at the $p<0.001, F=11.46$ level.

According to the decision tree that tested $V$. angustior occurrence with respect to landform types, surveys for new localities should concentrate on areas dominated by the

Table 2 Results of the CVA analysis showing the influence of studied factors on occurrence of both, $V$. moulinsiana and $V$. angustior

\begin{tabular}{llll}
\hline Variable & LambdaA & P & F \\
\hline flat_glaciofluvial & 0.39 & $<0.001$ & 79.51 \\
Holocene_flood-plains & 0.13 & $<0.001$ & 29.91 \\
intermediate_mountains & 0.13 & $<0.001$ & 36.96 \\
marshes & 0.04 & $<0.001$ & 11.26 \\
floodplain & 0.05 & $<0.001$ & 12.89 \\
valley & 0.03 & $<0.001$ & 11.06 \\
longitude & 0.03 & $<0.001$ & 9.53 \\
flooded_plains & 0.03 & $<0.001$ & 7.73 \\
latitude & 0.02 & 0.001 & 7.57 \\
morainic_plateaus & 0.01 & 0.019 & 4.08 \\
foothills & 0.00 & 0.146 & 1.98 \\
siliceous_uplands & 0.02 & 0.019 & 4.21 \\
altitude & 0.00 & 0.177 & 1.77 \\
terrace_flats & 0.00 & 0.425 & 0.85 \\
outwash_plains & 0.01 & 0.762 & 0.27 \\
hummocky_glacial & 0.00 & 0.743 & 0.30 \\
hummocky_peryglacial & 0.00 & 0.633 & 0.44 \\
terrace_plains & 0.00 & 0.773 & 0.27 \\
\end{tabular}

LambdaA percentage of variance explained by the variable alone; see Table 1 for abbreviations
Table 3 Results of the CVA analysis showing the influence of studied geographical factors on the occurrence of $V$. moulinsiana

\begin{tabular}{llll}
\hline Variable & LambdaA & P & F \\
\hline flat_glaciofluvial & 0.27 & $<0.001$ & 84.09 \\
marshes & 0.05 & $<0.001$ & 14.67 \\
valley & 0.07 & $<0.001$ & 28.24 \\
morainic_plateaus & 0.02 & 0.008 & 7.35 \\
lat & 0.02 & 0.035 & 4.56 \\
floodplain & 0.01 & 0.008 & 6.99 \\
long & 0.02 & 0.016 & 6.17 \\
Holocene_flood-plains & 0.01 & 0.027 & 5.00 \\
alt & 0.01 & 0.075 & 3.21 \\
intermediate_mountains & 0.00 & 0.563 & 0.34 \\
outwash_plains & 0.00 & 0.650 & 0.21 \\
hummocky_peryglacial & 0.00 & 0.503 & 0.44 \\
\hline
\end{tabular}

LambdaA percentage of variance explained by the variable alone; see Table 1 for abbreviations

landforms of outwash plains (see supplementary material 1 for diagram and detailed test statistics). In such regions, the probability of finding the species in a habitat fitting its requirements reaches $74.2 \%\left(p<0.001 ; \mathrm{Chi}^{2}=20.766\right)$. If other geomorphological forms dominated the area, surveys for $V$. angustior are the most effective in Holocene flood-plains $\left(p<0.001 ; \mathrm{Chi}^{2}=18.718\right)$. The intermediate mountains should be omitted; no $V$. angustior locality actually had been found during our surveys in this landform type despite the presence

Table 4 Results of the CVA analysis showing the influence of studied geographical factors on occurrence of $V$. angustior

\begin{tabular}{llll}
\hline Variable & LambdaA & P & F \\
\hline valley & 0.24 & $<0.001$ & 71.37 \\
floodplain & 0.10 & $<0.001$ & 32.41 \\
plains_accumulative & 0.05 & $<0.001$ & 20.59 \\
flooded_plains & 0.04 & $<0.001$ & 15.17 \\
longitude & 0.03 & 0.003 & 9.39 \\
marshes & 0.01 & 0.010 & 6.67 \\
latitude & 0.02 & 0.004 & 8.80 \\
outwash_plains & 0.01 & 0.033 & 4.68 \\
foothills & 0.01 & 0.301 & 1.13 \\
intermediate_mountains & 0.00 & 0.157 & 1.96 \\
altitude & 0.01 & 0.113 & 2.50 \\
siliceous_uplands & 0.00 & 0.265 & 1.19 \\
terrace_flats & 0.00 & 0.500 & 0.47 \\
holocene_flood-plains & 0.00 & 0.279 & 1.17 \\
morainic_plateaus & 0.00 & 0.362 & 0.83 \\
flat_glaciofluvial & 0.01 & 0.564 & 0.34 \\
hummocky_glacial & 0.00 & 0.332 & 0.91 \\
\hline
\end{tabular}

LambdaA percentage of variance explained by the variable alone; see Table 1 for abbreviations 
of potential habitats. In regions dominated by other landforms, the probability of finding the species is $53.7 \%$. In the modelling of the tree, the risk estimates for training and test samples were $0.241(\mathrm{SE}=0.04)$ and $0.289(\mathrm{SE}=0.42)$, respectively.

With respect to the tree that tested the occurrence of $V$. angustior in relation to the landscape types, the results show that surveys of the species will not be effective if concentrated on flooded plains $\left(p<0.001 ; \mathrm{Chi}^{2}=24.632\right)$ and accumulative plains, where the probability of finding the species is very low. The surveys, however, will be more productive if focused on other landscapes where the species occurred in $62.9 \%$ of the sites $\left(p<0.001 ; \mathrm{Chi}^{2}=25.369\right.$, see supplementary material 2 for a diagram and detailed test statistics).

Efficient surveys for $V$. angustior should omit margins of temporary water bodies (no such localities hosting the species were found, $\left.p<0.001 ; \mathrm{Chi}^{2}=16.95\right)$ and concentrate on valleys of small lowland rivers $\left(p<0.001 ; \mathrm{Chi}^{2}=19.53\right)$. In our study, the species occurred in $69.6 \%$ of such sites. The probability of finding $V$. angustior is further increased if examined localities are situated away from a river floodplain $\left(p=0.001\right.$; $\mathrm{Chi}^{2}=$ 11.573). In such cases, the species was found in $82.9 \%$ of the sites; the probability of occurrence was $27.3 \%$ otherwise. If the survey was conducted outside the small lowland valley, the probability of finding the species was $25.5 \%$. Searches performed within the floodplains under such conditions were ineffective $\left(p=0.023\right.$; $\left.\mathrm{Chi}^{2}=5.198\right)$, since no locality of $V$. angustior has been found in floodplains not associated with small river valleys in our surveys (Supplementary material 3 ).

To increase the efficiency of surveys for $V$. moulinsiana, the Holocene flood-plains $\left(p<0.001 ; \mathrm{Chi}^{2}=18.085\right)$ and intermediate mountains $\left(p<0.001 ; \mathrm{Chi}^{2}=16.646\right)$ landform types should be excluded. Focusing on other landform types will confer a $46.7 \%$ probability of finding the species (Supplementary material 4). Also, the type of landscape surrounding the site is influential to $V$. moulinsiana; the species is more frequent in the flat glaciofluvial type (60\%) compared to other landscapes considered in our study $(12 \% ; p<0.001$; $\left.\mathrm{Chi}^{2}=29.047\right)$. However, if other landscapes are to be surveyed, it is recommended that flooded plains ( $p=0.006$; $\left.\mathrm{Chi}^{2}=7.434\right)$ and accumulative plains $\left(p=0.011\right.$; $\mathrm{Chi}^{2}=$ 6.523) are omitted to increase effectiveness of the research (Supplementary material 5). The probability of finding $V$. moulinsiana is also low at the sites surrounding small, astatic waster bodies. Thus, it is justified to omit them in the surveys $\left(p<0.001 ; \mathrm{Chi}^{2}=14.254\right)$. The greatest effectiveness of $V$. moulinsiana surveys will be reached if they are concentrated on sites located in the valleys of small lowland rivers ( $p=0.001 ; \mathrm{Chi}^{2}=10.792$ ), where species occurrences were the most frequent within the floodplain area $(88.9 \%$ probability; $\left.p=0.0014 ; \mathrm{Chi}^{2}=6.091\right)$. Outside the small lowland valleys, the effort should be concentrated on surveying lake marshes $\left(p<0.001 ; \mathrm{Chi}^{2}=24.514\right)$, where the probability of finding the species was $66.7 \%$ (Supplementary material 6).

\section{Discussion}

Results of our study show that applying simple geographical data such as the geomorphic type of landform or landscape may increase substantially the efficiency of searching sites of $V$. angustior and V.moulinsiana. We show, that under the conditions of the studied area of Poland, it is possible for experienced malacologists to find these species in about $30 \%$ of tested sites if data in the literature regarding $V$. moulinsiana and $V$. angustior habitat preferences are followed (e.g. Pokryszko 1990; Cameron et al. 2003; Killeen 2003). However, when additional data on landscape and landform types are applied, the probability of successful surveying of these species could be increased up to $83 \%$ if undesirable locations are avoided.

The localities sampled for the present study were not distributed evenly in space, since the data resulted from nature conservation surveys performed for different purposes and their spatial distribution only partially depended on the authors. Results of variance partitioning analyses indicate however that the relationships of both species with spatial factors (longitude and latitude) are of secondary importance. The vast majority of variance explained by these factors was shared with the group of geomorphological variables. Thus, ecological factors were more important than geometric constraints (Baur et al. 2014). We therefore conclude that the uneven distribution of sampled localities does not influence the results substantially.

The major finding of our study is that the localities of $V$. angustior and $V$. moulinsiana are not distributed uniformly across wetlands in particular types of landforms and landscapes. Thus, the lack of these species does not indicate the lack of integrity of habitats located under certain geomorphological conditions. We suspect that such a situation is the result of differences in environmental conditions related to postglacial history as well as hydrogeological and climatic conditions related to this history which promoted formation of specific habitats (Price and Waddington 2000; Koralewska-Batura et al. 2010). According to our CVA analysis, both species are associated with young moraine landscapes and prefer landforms of glacial and glacio-fluvial deposition. This is consistent with data found in the current literature as both species are considered to be glacial relicts (Preece 2010). The studied vertiginids colonised areas of lowland fens, that are a succession stage of water bodies remaining after glacial retreat. Currently, such habitats still occur in the postglacial landscape, where alkaline fens and marshes are associated with lakes, as one of the final stages of lake succession (Richling and Ostaszewska 2005).

Moreover, our results suggest that $V$. moulinsiana and $V$. angustior are related to particular succession stages of lakes, with the former species occurring in more early phases of the habitat evolution. This way, V. moulinsiana is related to moraine plateaus dominated by the sediments of impermeable 
clay. Under such conditions, the groundwater level in lake marshes is constantly high, making the habitat suitable only for the climbing vertiginid species. On the other hand, our models show that $V$. angustior occurs more often in outwash plains dominated mainly by permeable substrata such as fine sands. Lakes found in such landscapes are usually shallower due to the stronger denudation processes (Galon 1972). Thus, lakes or lake remains occurring on outwash plains represent later stages of succession dominated by non-flooded but still highly moist habitats that fit the preferences of $V$. angustior.

Our models show that both vertiginids were found significantly more often across small river valleys. In the postglacial landscapes of Central European lowlands, marshes often occur in parts of river valleys located in depressions occupied in the past by lakes. Such marshes are rich in calcium carbonates (Galon 1972) and patchy (groundwater levels and humidity are diversified).

Although $V$. angustior and $V$. moulinsiana were frequently present in the small river valleys, they were absent from floodplains and supra-floodplains shaped during Holocenic fluvial accumulation (Holocene flood-plains). Considering that old Holocene river valleys are currently related to the floodplain areas of large rivers (Galon 1972), associated habitats are often influenced by the substantial variation in the level of water and flooding events, preventing formation of habitats suitable for the land snails (e.g. Cameron et al. 2003; Plum 2005). In contrast, floodplains of small rivers are more stable: the variation of water level is lower and habitats remain moist between flooding events. Such conditions are suitable for climbing species such as $V$. moulinsiana ("floodplain" variable was not significant) however not suitable for the litterdwellers such as $V$. angustior ("floodplain" variable was negatively related).

The "marshes" variable, referring to areas bordering lakes, was strongly related to V. moulinsiana. According to our study and data from the literature (Pokryszko 1990; Killeen 2003; Jueg 2004), this is one of the most typical habitats of this species. High moisture and lack of rapid changes in water level favour formation of suitable habitats for $V$. moulinsiana. Even if temporarily flooded, the species can survive by climbing up the plants (Pokryszko 1990; Hornung et al. 2003; Killeen 2003; Myzyk 2011). In case of $V$. angustior, however, survival depends on the morphology and succession stage of a lake, and, thus, habitats of lake marshes are usually too wet and do not always favour the species presence.

Both species are absent on mountainous regions probably due to the character of mountain spring fens. Such habitats, develop on shallow organo-mineral soils on slopes with significant inclination (Wołejko et al. 2008). Moreover, they are supplied by groundwater rich in calcium but poor in other nutrients (such as phosphorus and nitrogen), promoting the development of meso- and oligotrophic conditions, unfavourable for the snails studied (Sulikowska-Drozd and
Horsák 2007; Książkiewicz et al. 2012). However, according to our analyses, the potential of the presence of $V$. angustior cannot be excluded from sites located in upland and low mountain landscapes described as siliceous and aluminosiliceous erosive-forelands and low mountains (siliceous uplands). In these landscape types slopes are less inclined, and the area of fens is usually more extensive than at higher locations. The ground surface is covered with mosses, which have been shown to be a suitable habitat for $V$. angustior (Moorkens et al. 2012). Yet, compared to lowland habitats, vegetation is lower and fluctuations in groundwater levels differ, resulting in the less stable microclimate and higher amplitude of air humidity-and thus the absence of V. moulinsiana (Książkiewicz et al. 2013).

Following the relationships between distribution of localities of $V$. moulinsiana and $V$. angustior and geomorphology, the results of decision-tree modelling show that probability of successful surveying for these species could be increased up to $83 \%$ when some of the locations were avoided. The predictive power could be raised when data on climate, history of usage and habitat quality are included in the models.

Even without such detailed data, our study shows that it is possible to predict the occurrence of both Vertigo species and avoid surveying the places where they are absent based solely on rough geomorphological data. Pinpointing habitats potentially suitable for these species is important for the following reasons: (1) the area of such places can be small and they can remain overlooked during surveys; (2) these habitats are often eutrophicated and neglected during nature conservation assessments; and (3) Vertigo species are very small (height of shell about $2 \mathrm{~mm}$ ) and hard to find in the field. Thus, employing results from our study can make surveys for these vertiginids more efficient and can impact the effectiveness of their conservation (Guisan et al. 2006). By using our approach, potential conflicts between nature conservation and infrastructure development investments can be mitigated by specifying regions where the probability of the presence of $V$. angustior and V. moulinsiana is high (Stebbings and Killeen 1998). In this way, effective allocation of resources dedicated to surveys of the species can be performed (Marignani et al. 2014). We expect that the prediction models presented will be a useful tool in planning future surveys for $V$. angustior and $V$. moulinsiana both for the purposes of pre-investment nature conservation assessments and surveys aiming to better understand their ecology, distribution, and conservation status.

Acknowledgments The authors would like to thank Jonathan Ablett for valuable suggestions and help with the preparation of this paper. We greatly appreciate two anonymous referees for constructive and useful comments to the early version of the article. The study was partially supported by the Prometeo grant of the Secretariat for Higher Education, Science, Technology and Innovation of the Republic of Ecuador to the corresponding author of the paper. 
Open Access This article is distributed under the terms of the Creative Commons Attribution 4.0 International License (http:// creativecommons.org/licenses/by/4.0/), which permits unrestricted use, distribution, and reproduction in any medium, provided you give appropriate credit to the original author(s) and the source, provide a link to the Creative Commons license, and indicate if changes were made.

\section{References}

Bardgett RD (2005) The Biology of Soil: a community and ecosystem approach. Biology of Habitats. Oxford University Press, Oxford

Baur B, Meier T, Baur A, Schmera D (2014) Terrestrial gastropod diversity in an alpine region: disentangling effects of elevation, area, geometric constraints, habitat type and land-use intensity. Ecography 37:390-401

Bedford BL, Godwin KS (2003) Fens of the United States: distribution, characteristics, and scientific connection versus legal isolation. Wetlands 23:608-629

Borcard D, Legendre P, Drapeau P (1992) Partialling out the spatial component of ecological variation. Ecology 73:1045-1055

Cameron RAD, Colville B, Falkner G, Holyoak A, Hornung E, Killeen IJ, Moorkens EA, Pokryszko MB, Proschwitz T, Tattersfield P, Valovirta I (2003) Species accounts for snails of genus Vertigo listed in Annex II of the Habitat Directive: $V$. angustior, $V$. genesii, $V$. geyeri and $V$. moulinsiana (Gastropoda: Pulmonata: Vertiginidae). Heldia 5:151-157

Colling M, Schröder, E (2005a) Vertigo angustior (Jeffreys, 1830). In: Petersen B, Ellwanger G, Biewald G, Hauke U, Ludwig G, Pretscher P, Schröder E, Ssymanka A (eds) Das europäische Schutzgebietssystem Natura 2000. Ökologie und Verbreitung von Arten der FFH-Richtlinie in Deutschland. Band 1: Pflanzen und Wirbellose. Schriftenreihe für. Landschaftspflege und Naturschutz 69:665-676

Colling M, Schröder E (2005b) Vertigo moulinsiana (Dupuy, 1849). In: Petersen B, Ellwanger G, Biewald G, Hauke U, Ludwig G, Pretscher P Schröder E, Ssymanka A (eds) Das europäische Schutzgebietssystem Natura 2000. Ökologie und Verbreitung von Arten der FFH-Richtlinie in Deutschland. Band 1: Pflanzen und Wirbellose. Schriftenreihe für Landschaftspflege und Naturschutz 69:694-706

Cook A (2001) Behavioural ecology: on doing the right thing, in the right place at the right time. In: Barker GM (ed) The biology of terrestrial molluscs. CABI Publishing, p 447-488

Egoh BN, Paracchini ML, Zulian G, Schägner JP, Bidoglio G (2014) Exploring restoration options for habitats, species and ecosystem services in the European Union. Journal of Applied Ecology 51:899-908

Galon R (1972) Geomorfologia Polski, t. 2: Niż Polski. PWN Warszawa

Guisan A, Broennimann O, Engler R, Vust M, Yoccoz NG, Lehmann A, Zimmermann NE (2006) Using niche-based models to improve the sampling of rare species. Conservation Biology 20:501-511

Hornung E, Majors G, Fehér Z, Varga A (2003) An overview of the Vertigo species in Hungary: their distribution and habitat preferences. Heldia 5:51-57

Horsàk M (2003) How to sample mollusc communities in mires easily. Malacologica Bohemoslovaca (Československá slimač) 2:11-14

Jankowiak A, Bernard R (2013) Coexistence or spatial segregation of some Vertigo species (Gastropoda: Vertiginidae) in a Carex rich fen in Central Poland? Journal of Conchology 41:399-406

Jueg U (2004) Die Verbreitung und Ökologie von Vertigo moulinsiana (Dupuy, 1849) in Mecklenburg-Vorpommern (Gastropoda: Stylommatophora: Vertiginidae). Malakologische Abhandlungen 22:87-124
Kass GV (1980) An exploratory technique for investigating large quantities of categorical data. Applied Statistics 29:119-127

Killeen IJ (2003) Ecology of Desmoulin's Whorl Snail Vertigo moulinsiana. Conserving Natura 2000 Rivers. Ecology Series 6:125

Koralewska-Batura E, Błoszyk J, Gołdyn B, Szybiak K, Lesicki A, Napierała A (2010) Materials to the knowledge of the molluscs (Mollusca) in Wielkopolska (West-Central Poland). I. Historical and general remark. Folia Malacologica 18:15-28

Książkiewicz Z (2010) Higrofilne gatunki poczwarówek północnozachodniej Polski. Poradnik ochrony siedlisk poczwarówki zwężonej Vertigo angustior (Jeffreys 1830) i poczwarówki jajowatej Vertigo moulinsiana (Dupuy 1849). Wydawnictwo Klubu Przyrodników, Świebodzin

Książkiewicz Z (2014) Impact of land use on populations of Vertigo moulinsiana (Dupuy, 1949) and Vertigo angustior Jeffreys, 1839 (Gastropoda: Pulmonata: Vertiginidae): Ilaka River valley (W. Poland). Folia Malacologica 22:277-282

Książkiewicz Z, Biereżnoj-Bazille U, Krajewski Ł, Gołdyn B (2015) New records of Vertigo geyeri Lindholm, 1925, V. moulinsiana (Dupuy, 1849) and V. angustior Jeffreys, 1830 (Gastropoda: Pulmonata: Vertiginidae) in Poland. Folia Malacologica. http://dx. doi.org/10.12657/folmal.023.006

Książkiewicz Z, Kasiewicz K, Gołdyn B (2013) Microhabitat requirements of five rare vertiginid species (Gastropoda, Pulmonata, Vertiginidae) in wetlands of western Poland. Malacologia 56:95106

Książkiewicz Z, Lipińska A, Zając K, Barga-Więcławska JA (2012) Poczwarówka zwężona Vertigo angustior (Jeffreys, 1830). In: Makomaska-Juchiewicz M, Baran P (eds) Monitoring gatunków zwierząt. Przewodnik monitoringu. Część II. GIOŚ, Warszawa, pp 482-503

Lipińska A, Książkiewicz Z, Zając K, Barga-Więcławska JA (2012) Poczwarówka jajowata Vertigo moulinsiana (Dupuy, 1849). In: Makomaska-Juchiewicz M, Baran P (eds) Monitoring gatunków zwierząt. Przewodnik monitoringu. Część II. GIOŚ, Warszawa, pp 463-481

Lydeard C, Cowie RH, Ponder WF, Bogan AE, Bouchet P, Clark SA, Cummings KS, Frest TJ, Gargominy O, Herbert DG, Hershler R, Perez KE, Roth B, Seddon M, Strong EE, Thompson FG (2004) The global decline of nonmarine mollusks. BioScience 54:321-330

Marignani M, Bacchetta G, Bagella S, Caria MC, Delogu F, Farris E, Fenu G, Filigheddu R, Blasi C (2014) Is time on our side? Strengthening the link between field efforts and conservation needs. Biodiversity and Conservation 23:421-431

Moorkens E, Killeen IJ, Seddon M (2012) Vertigo angustior. IUCN 2013. IUCN Red List of Threatened Species. Version 2013.2. www. iucnredlist.org. Accessed 05.09.2014

Murugesan P, Muniasamy M, Muthuvelu S, Vijayalakshmi S, Balasubramanian T (2011) Utility of benthic diversity in assessing the health of an ecosystem. Indian Journal of Marine Sciences 40: 783-793

Myzyk S (2011) Contribution to the biology of ten vertiginid species. Folia Malacologica 19:55-80

Norris A, Colville B (1974) Notes on the occurrence of Vertigo angustior Jeffreys in Great Britain. Journal of Conchology 28:141-154

Oke CO (2013) Terrestrial mollusc species richness and diversity in Omo forest reserve, Ogun state, Nigeria. African Invertebrates 54:93-104

Ormerod SJ, Durance I, Terrier A, Swanson AM (2010) Priority wetland invertebrates as conservation surrogates. Conservation Biology 24: $573-582$

Plum N (2005) Terrestrial invertebrates in flooded grassland: a literature review. Wetlands 25(3):721-737

Pokryszko BM (1990) The Vertiginidae of Poland (Gastropoda: Pulmonata: Vertiginidae) - a systematic monograph. Annales Zoologici 43:133-257 
Pokryszko BM (2003) Vertigo in Continental Europe-autecology, threats and conservation status (Gastropoda, Pulmonata: Vertiginidae). Heldia 5:13-25

Ponder WF, Walker KF (2003) From mound springs to mighty rivers: the conservation status of freshwater molluscs in Australia. Aquatic Ecosystem Health and Management 6:19-28

Preece RC (2010) The molluscan fauna of the Cromerian type site at West Runton, Norfolk. Quaternary International 228:53-62

Price JS, Waddington JM (2000) Advances in Canadian wetland hydrology and biogeochemistry. Hydrological Processes 14:1579-1589

Richling A, Ostaszewska K (2005) Geografia fizyczna Polski. Polskie Wydawnictwo Naukowe, Warszawa

Šefferová Stanová V, Šeffer J, Janák M (2008) Management of Natura 2000 habitats. 7230 Alkaline fens. European Communities

Stebbings RE, Killeen IJ (1998) Translocation of habitat for the snail Vertigo moulinsiana in England. Journal of Conchology, Special Publication 2:191-204

Steinitz O, Heller J, Tsoar A, Rotem D, Kadmon R (2005) Predicting regional patterns of similarity in species composition for conservation planning. Conservation Biology 19:1978-1988
Stewart TW (2006) The freshwater gastropods of Iowa (1821-1998): species composition, geographic distributions, and conservation concerns. American Malacological Bulletin 21:59-75

Sulikowska-Drozd A, Horsák M (2007) Woodland mollusc communities along environmental gradients in the East Carpathians. Biologia 62: 201-209

ter Braak CJF (1996) Unimodal methods to relate species to environment. Centre for Biometry Wageningen (DLO Agricultural Mathematics Group), Wageningen

ter Braak CJF, Šmilauer P (2002) CANOCO reference manual and CanoDraw for windows user's guide: software for canonical community ordination (version 4.5). Microcomputer Power, Ithaca, NY, USA

von Proschwitz T (2003) A review of the distribution, habitat selection and conservation status of the species of the genus Vertigo in Scandinavia (Denmark, Norway and Sweden) (Gastropoda: Pulmonata: Vertiginidae). Heldia 5:27-50

Wołejko L, Stańko R, Pawlikowski P (2008) Poradnik utrzymania i ochrony siedliska przyrodniczego 7230-torfowiska alkaliczne. Klub Przyrodników, Świebodzin-Warszawa 